\title{
Antioxidant, genotoxic and antigenotoxic activities of daphne gnidium leaf extracts
}

\author{
Fadwa Chaabane', Jihed Boubaker ${ }^{1}$, Amira Loussaif ${ }^{1}$, Aicha Neffati ${ }^{1}$, \\ Somaya Kilani-Jaziri ${ }^{1}$, Kamel Ghedira ${ }^{1}$ and Leila Chekir-Ghedira ${ }^{1,2^{*}}$
}

\begin{abstract}
Background: Plants play a significant role in maintaining human health and improving the quality of human life. They serve humans well as valuable components of food, as well as in cosmetics, dyes, and medicines. In fact, many plant extracts prepared from plants have been shown to exert biological activity in vitro and in vivo. The present study explored antioxidant and antigenotoxic effects of Daphne gnidium leaf extracts.

Methods: The genotoxic potential of petroleum ether, chloroform, ethyl acetate, methanol and total oligomer flavonoid (TOF) enriched extracts from leaves of Daphne gnidium, was assessed using Escherichia coli PQ37. Likewise, the antigenotoxicity of the same extracts was tested using the "SOS chromotest test". Antioxidant activities were studied using non enzymatic and enzymatic method: NBT/Riboflavine and xantine oxidase.

Results: None of the different extracts produced a genotoxic effect, except TOF extract at the lowest tested dose. Our results showed that $D$. gnidium leaf extracts possess an antigenotoxic effect against the nitrofurantoin a mutagen of reference. Ethyl acetate and TOF extracts were the most effective in inhibiting xanthine oxidase activity. While, methanol extract was the most potent superoxide scavenger when tested with the NBT/Riboflavine assay.

Conclusions: The present study has demonstrated that D. gnidium leaf extract possess antioxidant and antigenotoxic effects. These activities could be ascribed to compounds like polyphenols and flavonoid. Further studies are required to isolate the active molecules.
\end{abstract}

Keywords: Daphne gnidium, Antioxidant, Antigenotoxic

\section{Background}

The use of medicinal plants has always been part of human culture. The World Health Organization estimates that up to $80 \%$ of the world's population relies on traditional medicinal system for some aspect of primary health care [1]. In some countries, governments encourage the use of indigenous forms of medicine rather than expensive imported drugs [2].

Extracts from plants have been reported to be effective in treating febrile illnesses, sleeping sickness, wounds, diarrhoea, reproductive and liver problems, circulatory and respiratory problems and parasitic infections [3-5]. Recently, there has been a great increase of interest in natural antioxidant of plant origin since they are viewed

\footnotetext{
* Correspondence: leila.chekir@laposte.net

'Unité de Pharmacognosie/Biologie Moléculaire 99/UR/07-03, Faculté de Pharmacie de Monastir, Monastir 5000, Tunisie

¿Laboratoire de Biologie Cellulaire et Moléculaire, Faculté de Médicine Dentaire, de Monastir, Rue Avicenne 5000, Tunisie
}

as promising therapeutic agents for free radical pathologies and also found to be useful as nutraceuticals due to their impact on the status of human health and disease prevention [6,7].

The protection afforded by plants has been attributed to various phenolic compounds which are increasingly becoming of interest in the food industry because they retard oxidative degradation of lipids and thereby improve food quality [8].

Reactive oxygen species (ROS), are known to cause the oxidation of biomolecules leading to cellular damage. The tissue injury caused by ROS may include DNA and protein damages, and oxidation of important enzymes. These events could consequently lead to the occurrence of various free radical-related diseases. In the human body, the toxic effects of ROS are combated regularly by a number of endogenous defence and protective mechanisms which include various enzymes and non- 
enzymatic antioxidants. These self-defence systems may also be supported by antioxidative compounds taken as foods, cosmetics and herb medicine [8].

It is also important to note that most of the traditional medicinal plants have never been the subject of exhaustive toxicological tests such as is required for modern pharmaceutical compounds. Based on their traditional use for long periods of time they are often assumed to be safe. However, research has shown that a lot of plants which are used as food ingredients or in traditional medicine have in vitro mutagenic [9-11] or toxic and carcinogenic [12] properties.

At present, there are several antigenotoxicity assays available, which include the micronucleus test, somatic mutation and recombination test (SMART), sister chromatid exchange (SCE) assay and the single cell gel electrophoresis (SCGE) or comet assay. The abovementioned assays may involve a longer analysis time, a high cost, and specialized skill or may require addition of expensive reagents. Therefore, short-term bacterial assay: SOS chromotest assay is useful and gives an estimation of the genotoxic/antigenotoxic potential of substances [13].

Daphne gnidium is an evergreen shrub that grows in the Mediterranean area and can grow to a height of $2 \mathrm{~m}$ [12]. In folk medicine the infusion of the leaves is used as hypoglycemic [14] and to treat skin diseases $[15,16]$. This plant is also used in traditional textile [17] dyeing.

However, Daphne gnidium is considered dangerous because of its high toxicity. It produces headache, shivering, paleness, pupil dilatation, mouth and lips swelling, difficulty of deglutition, diarrhea and digestive spasms, convulsion, pulmonary disorders and death $[15,18]$. Accordingly, in the present study, the antioxidant properties of Daphne gnidium leaf extracts were evaluated through biochemical assays: the xanthine/xanthine oxidase enzymatic assay system, and the NBT/Riboflavine assay. Furthermore, the genotoxic and antigenotoxic activities were tested using the SOS chromotest.

\section{Method}

\section{Plant material}

The leaves of D. gnidium were collected in the region of Bizerte (latitude: 37.27 , height: 22) situated in the North of Tunisia in November 2009. Botanical identification was carried out by Prof. M. Chaieb (Department of Botany, Faculty of Sciences, University of Sfax, Tunisia), according to the flora of Tunisia [12]. A voucher specimen (D9-11-09) has been deposited in the laboratory of Pharmacognosy, Faculty of Pharmacy of Monastir, Tunisia. The leaves were shade dried, powdered and stored (at $25^{\circ} \mathrm{C}$ under $40 \%$ of relative humidity) in a tightly closed container for further use.

\section{Preparation of plant extracts}

In order to obtain an extract enriched with total oligomer flavonoids (TOF), powder $(200 \mathrm{~g})$ was macerated in water/acetone mixture $(1: 2, \mathrm{~V} / \mathrm{V})$, during $24 \mathrm{~h}$ with continuous stirring. The extract was filtered and the acetone was evaporated under low pressure in order to obtain an aqueous phase. The tannins were partially removed by precipitation with an excess of $\mathrm{NaCl}$ during $24 \mathrm{~h}$ at $5^{\circ} \mathrm{C}$, then we recovered the supernatant. This latter was extracted with ethyl acetate, concentrated and precipitated with an excess of chloroform. The precipitate was separated and yielded the TOF extract which was dissolved in water [19]. Petroleum ether (PE), chloroform $(\mathrm{CHl})$, ethyl acetate $(\mathrm{EA})$ and methanol $(\mathrm{MeOH})$ extracts were obtained by the Soxhlet appartus $(6 \mathrm{~h})$. The four types of extract, with different polarities, were concentrated to dryness and the residue was kept at $4{ }^{\circ} \mathrm{C}$. The extracts were concentrated to dryness and resuspended in DMSO. These extracts were used at the concentrations of $0.50,0.75,1.5$ and $3 \mathrm{mg} / \mathrm{ml}$ in the Xanthine/ xanthine oxydase assay, and at $0.25,0.5,1,2$ and $5 \mathrm{mg} /$ $\mathrm{ml}$ in the NBT/Riboflavine assay. The doses tested in the SOS Chromotest assay were 50,250 , and $500 \mu \mathrm{g}$ /assay for petroleum ether and chloroform extracts, 5, 15 and $30 \mu \mathrm{g} /$ assay with the ethyl acetate and TOF extracts and 50, 100 and $200 \mu \mathrm{g} /$ assay with the methanol extract.

\section{Preliminary photochemical analysis}

Plant materials were screened for the presence of tannins, flavonoids and coumarins [20]. Two milligrams of each extract were separately dissolved in $2 \mathrm{ml}$ of the adequate solvent. The identification of major chemical groups was carried by thin layer chromatography (TLC) on silica gel 60 F254 Merck (layer thickness $0.25 \mathrm{~mm}$ ) as follows; for flavonoids, spots were visualized with $1 \%$ aluminium chloride solution in methanol under UV (366 nm) [21]. Coumarins were detected under UV (366 nm) thanks to their blue fluorescence which becomes intense after spraying with $10 \%$ potassium hydroxide solution in ethanol. The test for tannins was carried out with $\mathrm{Fe} \mathrm{Cl}_{3}$.

\section{Bacterial tester strain}

Escherichia coli $P Q 37$ strain was kindly provided by Prof. M. Quillardet (Institut Pasteur, Paris, France). Frozen permanent copies of the tester strain were prepared and stored at $-80^{\circ} \mathrm{C}$.

\section{Determination of total polyphenol and flavonoid content}

The polyphenol content of $D$. gnidium was quantified at $25^{\circ} \mathrm{C}$ by the Folin-Ciocalteau reagent [22,23]. Aliquots of test samples $(100 \mu \mathrm{l})$ were mixed with $2.0 \mathrm{ml}$ of $2 \%$ $\mathrm{Na}_{2} \mathrm{CO}_{3}$ and incubated at room temperature for $2 \mathrm{~min}$. After the addition of $100 \mu \mathrm{l} 50 \%$ Folin-Ciocalteau phenol reagent, the reaction tube was further incubated for 
$30 \mathrm{~min}$ at room temperature, and finally absorbance was read at $720 \mathrm{~nm}$. Gallic acid $(0.2 \mathrm{mg} / \mathrm{ml})$ was used as a standard. Polyphenol content was expressed according to the following formula:

$$
\% \text { Polyphenols }=\left(\frac{\left[\frac{D O_{\text {Extarct }} \times 0.2}{\text { DOGalicacid }}\right]}{\text { Extract concentration }}\right) \times 100
$$

A known volume of each extract was placed in a $10 \mathrm{ml}$ volumetric flask to estimate flavonoid content [24]. After addition of $75 \mu \mathrm{l}$ of $\mathrm{NaNO}_{2}$ (5\%), $150 \mu \mathrm{l}$ of freshly prepared $\mathrm{AlCl}_{3}(10 \%)$, and $500 \mu \mathrm{l}$ of $\mathrm{NaOH}(1 \mathrm{~N})$, the volume was adjusted with distilled water until $2.5 \mathrm{ml}$. After 5 min incubation, the total absorbance was measured at $510 \mathrm{~nm}$. Quercetin $(0.05 \mathrm{mg} / \mathrm{ml})$ was used as a standard. Flavonoids content was expressed according to the following formula:

$$
\% \text { Flavonoids }=\left(\frac{\left[\frac{D O_{\text {Extarc }} \times 0.05}{D O_{\text {Quercitin }}}\right]}{\text { Extract concentration }}\right) \times 100
$$

\section{Determination of tannin content}

Extraction of tannin in the sample was achieved by dissolving $5 \mathrm{~g}$ of sample in $50 \mathrm{ml}$ of distilled water in a conical flask, allowing the mixture to stand for $30 \mathrm{~min}$ with shaking the flask at 10 min intervals, and then centrifuging at $5000 \times \mathrm{x}$ to obtain a supernatant (tannin extract). The extract was diluted to $100 \mathrm{ml}$ in a standard flask using distilled water.

Five milliliters of the diluted extract and $5 \mathrm{ml}$ of standard tannic acid $(0.1 \mathrm{~g} / \mathrm{l})$ were measured into two different $50 \mathrm{ml}$ volumetric flasks. One milliliter of Folin-Denis reagent was added to each flask followed by $2.5 \mathrm{ml}$ of saturated sodium carbonate solution. The solutions were made up to the $50 \mathrm{ml}$ mark with distilled water and incubated at room temperature $\left(20-30^{\circ} \mathrm{C}\right)$ for $90 \mathrm{~min}$. The absorption of these solutions was measured against that of the reagent blank (containing $5 \mathrm{ml}$ of distilled water in place of extract or standard tannic acid solution) in a Genesys (Wisconsin, USA) spectrophotometer at $760 \mathrm{~nm}$ wavelength [25]. Tannin content was calculated in triplicate according to the following formula:

$$
\% \text { Tanins }=\left[\frac{\frac{D O_{\text {Extract }}}{\epsilon} \times 1}{\text { Extract concentration }}\right] \times 100
$$

where $\epsilon$; molar extinction coefficient $\left(\mathrm{l}^{\mathrm{g}} \mathrm{g}^{-1} \cdot \mathrm{cm}^{-1}\right)$ of tannic acid $\left(=3.27 \mathrm{~L} \mathrm{~g}^{-1} \mathrm{~cm}^{-1}\right)$ and $\mathrm{l}=1 \mathrm{~cm}$.

\section{Genotoxicity assay}

The SOS chromotest with Escherichia coli PQ37 strain was performed according to the procedure described by Quillardet and Hofnung [26]. An overnight culture
(16 hours) of E. coli PQ37 (100 $\mu \mathrm{L})$ was added to $5 \mathrm{ml}$ of fresh medium and incubated for $2 \mathrm{~h}$ at $37^{\circ} \mathrm{C}$. One milliliter of this culture (approximate density $2 \times 10^{8}$ cells/ $\mathrm{ml}$ ) was diluted with $9 \mathrm{ml}$ of fresh Luria broth medium. A fraction of $0.6 \mathrm{ml}$ was transferred into a series of glass test tubes, each containing $20 \mu \mathrm{l}$ gradual dilutions of the compound to be tested. The mixtures were incubated with shaking for $2 \mathrm{~h}$ at $37^{\circ} \mathrm{C}$. In order to determine the $\beta$-galactosidase ( $\beta$ gal) activity induced by DNAdamaging compound, $2.7 \mathrm{ml}$ of $\mathrm{B}$ buffer $\left[\mathrm{Na}_{2} \mathrm{HPO}_{4}\right.$ (112.7 mM), $\mathrm{NaH}_{2} \mathrm{PO}_{4} \mathrm{H}_{2} \mathrm{O}(45.8 \mathrm{mM}), \mathrm{KCl}(10 \mathrm{mM})$, $\mathrm{MgSO}_{4} \cdot 7 \mathrm{H}_{2} \mathrm{O}(0.1 \mathrm{mM})$, sodium dodecyl sulfate (SDS) (3.46 mM), mercaptoethanol $2.7 \mathrm{~mL} / \mathrm{L}$, adjusted to $\mathrm{pH}$ $7]$, and $0.6 \mathrm{~mL}$ of $0.4 \%$ Ortho-Nitrophenyl- $\beta$-galactoside (ONPG) solution were added to each tube of one of the sets. Whereas to determine the constitutive alkaline phosphatase (AP) activity, $2.7 \mathrm{ml}$ of $\mathrm{P}$ buffer [tris(hydroxymethyl)-aminomethane (1 M), SDS (3.46 mM) dissolved in distilled water and adjusted to $\mathrm{pH} 8.8$ with $\mathrm{HCl}$, replaced the $\mathrm{B}$ buffer, and $0.6 \mathrm{ml}$ of $0.4 \% \mathrm{p}$ nitrophenyl phosphate (PNPP) solution was added to each tube of the second set. After incubation, the conversion of ONPG was stopped with $2 \mathrm{ml}$ of $1 \mathrm{M}$ sodium carbonate solution and that of PNPP with $2 \mathrm{ml}$ of $1.5 \mathrm{~N}$ sodium hydroxide solution. The absorbance was measured at $420 \mathrm{~nm}$ against a blank without bacteria. The induction factor (IF) was calculated as the ratio of $R_{C} /$ $R_{0}$, where $R_{C}$ is equal to $\beta$ gal activity/AP activity determined for the test compound at concentration $C$, and $R_{0}$ is equal to $\beta$ gal activity/AP activity in the absence of test compound. The $\beta$ gal and AP activities were calculated according to the method recommended by Quillardet and Hofnung [26]. Each dose was tested in triplicate.

The doses tested in the SOS Chromotest assay were 50, 250, and $500 \mu \mathrm{g} / \mathrm{assay}$ for petroleum ether and chloroform extracts, 5, 15 and $30 \mu \mathrm{g} /$ assay with the ethyl acetate and TOF extracts and 50, 100 and $200 \mu \mathrm{g} /$ assay with the methanol extract.

According to Kevekordes et al. [27], compounds are classified as non-genotoxic if the induction factor (IF) remains $<1.5$, as marginally genotoxic if the induction factor ranges between 1.5 and 2 and as genotoxic if the IF exceeds 2 .

\section{Antigenotoxicity assay}

Inhibition of bacterial genotoxicity was tested in $E$. coli PQ37 strain. Twenty microliters of nitrofurantoin solution $(5 \mu \mathrm{g} /$ assay) was added into tubes with $20 \mu \mathrm{l}$ of tested concentration of extracts, which were dissolved in DMSO and tested in triplicate [26]. Antigenotoxicity was expressed as percentage inhibition of genotoxicity induced by nitrofurantoin according to the formula:

$$
\operatorname{Inhibition}(\%)=100-\left(I F_{1}-I F_{0} / I F_{2}-I F_{0}\right) \times 100
$$


where $\mathrm{IF}_{1}$ is the induction factor in the presence of the test compound and the mutagen, $\mathrm{IF}_{2}$ the induction factor in the absence of the test compound and in the presence of the mutagen, and $\mathrm{IF}_{0}$ the induction factor of the untreated cells.

Dose of $5 \mu \mathrm{g} /$ assay of nitrofurantoin was chosen for the antigenotoxicity studies, since this dose was not toxic and induced a significant SOS response [28].

\section{Evaluation of xanthine oxidase inhibition effect}

The enzyme xanthine oxidase catalyzes the oxidation of xanthine to uric acid. During this reaction, molecular oxygen acts as an electron acceptor, producing superoxide radicals according to the following equation:

$$
\text { Xanthine }+\mathrm{O}_{2}+\mathrm{H}_{2} \mathrm{O} \rightarrow \text { uricacid }+\mathrm{O}_{2}+\mathrm{H}_{2} \mathrm{O}_{2}
$$

Xanthine oxidase activity was evaluated under aerobic condition [29], by the spectrophotometric measurement of the production of uric acid from xanthine. The inhibition of xanthine oxidase activity was followed by measuring the increase of uric acid absorbance at $290 \mathrm{~nm}$ as proposed by Cimanga et al. [30], while the superoxide anion scavenging activity was detected spectrophotometrically with the nitrite method described by Oyangagui [31]. The assay mixture consisted of $100 \mu \mathrm{l}$ of compound test solution, $200 \mu \mathrm{l}$ xanthine (final concentration $0.1 \mathrm{mM}$ ) as the substrate, hydroxylamine (final concentration $0.2 \mathrm{mM}), 200 \mu \mathrm{l}$ EDTA $(0.1 \mathrm{mM})$ and $300 \mu \mathrm{l}$ distilled water. The reaction was initiated by adding $200 \mu \mathrm{l}$ xanthine oxidase $(11 \mathrm{mU})$ dissolved in phosphate buffer $\left(\mathrm{KH}_{2} \mathrm{PO}_{4}, 0.2 \mathrm{M}, \mathrm{pH} 7.5\right)$. The assay mixture was incubated at $37^{\circ} \mathrm{C}$ for $30 \mathrm{~min}$. Before measuring the uric acid production at $290 \mathrm{~nm}$, the reaction was stopped by adding $100 \mu \mathrm{l}$ of $0.58 \mathrm{mM}$ HCL. The absorbance was measured spectrophotometrically against a blank solution prepared as described above, but replacing xanthine oxidase with buffer solution (no production of uric acid). A control solution without test compound was prepared in the same manner as the assay mixture to measure the total uric acid production. The uric acid production was calculated from the differential absorbance. The doseeffect curve for each extract was linearized by regression analysis and used to derive the $\mathrm{IC}_{50}$ values. Extracts were used at the concentrations of $0.50,0.75,1.5$ and $3 \mathrm{mg} /$ $\mathrm{ml}$.

\section{Determination of superoxide radical scavenging effect}

The test implements two principal reactions [32]:

$$
\begin{aligned}
& \left.2 \mathrm{NBTH} \rightarrow \mathrm{NBT}+\mathrm{NBTH}_{2} \text { (Formazan }\right) \\
& \mathrm{NBTH}+\mathrm{O}_{2} \leftrightarrow \mathrm{NBT}+\mathrm{O}_{2}
\end{aligned}
$$

When the riboflavin is photochemically activated, it reacts with the NBT to give NBTH that leads to formazan according to the reaction (a). In presence of oxygen, concentrations of radical species are controlled by the quasi equilibrium (b). Thus, superoxide anions appear indirectly when the test is performed under aerobic conditions. In the presence of an antioxidant that can donate an electron to NBT, the purple color typical of the formazan decays, a change that can be followed spectrophotometrically at $560 \mathrm{~nm}$.

The assay was based on the capacity of the samples to enhance the aerobic photochemical reduction of nitroblue tetrazolium (NBT) in the presence of riboflavine [33]. For all assays, the reaction mixture contained EDTA $(6.5 \mathrm{mM})$, riboflavine $(4 \mu \mathrm{M})$, NBT $(96 \mu \mathrm{M})$ and phosphate buffer (51.5 mM, pH 7.4). The volume of tested sample was of $100 \mu \mathrm{l} / \mathrm{assay}$. The occurrence of superoxide and/or free radicals was indirectly evaluated by the increase in absorbance of formazan at $560 \mathrm{~nm}$, after $30 \mathrm{~min}$ of incubation at $30^{\circ} \mathrm{C}$ from the beginning of illumination [34]. The assay run without any test compound (containing only NBT-riboflavine) was used as the reference. All assays were realized in triplicate.

$$
\text { Scavenging } \%\left(\frac{O D_{\text {controle }}-O D_{\text {sample }}}{O D_{\text {controle }}}\right) \times 100
$$

The reference substance (quercetine) was assayed at $0.5,1$ and $2 \mathrm{mg} / \mathrm{ml}$ concentrations with three repetitions. Extracts were tested at $0.25,0.5,1,2$ and $5 \mathrm{mg} / \mathrm{ml}$ in triplicate.

\section{Results}

\section{Phytochemical study}

The TOF, ethyl acetate and methanol extracts showed the presence of various quantities of flavonoids and tannins. Ethyl acetate, chloroform and TOF extracts showed the presence of coumarins. TOF extract showed the highest content of polyphenols, flavonoids and tannins compared to the other tested extracts with respective values of 372.47 equivalent of gallic acid, 494.57 equivalent of quercetin and 163.73 equivalent of tannic acid (Table 1).

Table 1 Quantitative phytochemical screening of extracts from $D$. gnidium leaves

\begin{tabular}{lccc}
\hline Extracts & \multicolumn{3}{c}{ Extract content } \\
\cline { 2 - 4 } & $\begin{array}{c}\text { Polyphenols } \\
\text { (gallic acid } \\
\text { equivalents) }\end{array}$ & $\begin{array}{c}\text { Flavonoids } \\
\text { (Quercitin } \\
\text { equivalents) }\end{array}$ & $\begin{array}{c}\text { Tannins } \\
\text { (Tannic acid } \\
\text { equivalents) }\end{array}$ \\
\hline Chloroform extract & 104.41 & - & - \\
Ethyl acetate extract & 227.75 & 264.57 & 136.64 \\
Methanol extract & 157.47 & 114.57 & 116 \\
TOF extract & 372.47 & 494.57 & 163.73 \\
\hline
\end{tabular}




\section{Genotoxic activity of extracts}

In a series of experiments preceding the antimutagenicity studies, it was ascertained that the different amounts of extracts added to the indicator bacteria does not influence their viability.

It was revealed that tested extracts, at the concentrations used, have a very low effect on the induction factor in the SOS chromotest.. Based on this, D.gnidium tested extracts are evaluated as non genotoxic, except the TOF extract, which can be classified as marginally genotoxic $(\mathrm{IF}=2)($ Table 2).

\section{Antigenotoxicity assay}

The IFs of nitrofurantoin were determined at various concentrations of D. gnidium extracts, and it was revealed that increasing concentrations of TOF, methanol, ethyl acetate and chloroform extracts significantly decreased nitrofurantoin induced genotoxicity (IF).

IFs decreased from 23.56 to $17.37,6.35$ at the dose of $500 \mu \mathrm{g} / \mathrm{ml}$ for petroleum ether and chloroform extracts respectively, to 8.46 and 12.86 at the dose of $30 \mu \mathrm{g} / \mathrm{ml}$ for ethyl acetate and TOF extracts respectively and to 7.50 at the dose of $200 \mu \mathrm{g} / \mathrm{ml}$ for the methanol extract.

The highest inhibition percentages of genotoxicity obtained with the above-mentioned extracts were $47.38 \%$ (at a concentration of $30 \mu \mathrm{g} /$ assay of TOF

Table 2 Genotoxicity induced by extracts from D. gnidium leaves

\begin{tabular}{|c|c|c|c|c|}
\hline Extracts & $\begin{array}{c}\text { Dose } \\
\text { ( } \mu \mathrm{g} / \mathrm{assay})\end{array}$ & $\begin{array}{c}\beta \text {-gal } \\
\text { (UE) }\end{array}$ & $\begin{array}{l}\text { PA } \\
\text { (UE) }\end{array}$ & IF \\
\hline Nitrofurantoin & 5 & $42,18 \pm 0,092$ & $11,19 \pm 0,0021$ & 23,56 \\
\hline NC & 0 & $2,28 \pm 0,031$ & $11,27 \pm 0,017$ & 1 \\
\hline \multirow[t]{3}{*}{ Petroleum ether extract } & 50 & $2,26 \pm 0,043$ & $13,95 \pm 0,017$ & 0,81 \\
\hline & 250 & $1,96 \pm 0,002$ & $14,35 \pm 0$ & 0,68 \\
\hline & 500 & $2,13 \pm 0,012$ & $13,51 \pm 0,01$ & 0,79 \\
\hline \multirow[t]{3}{*}{ Chloroform extract } & 50 & $1,27 \pm 0,004$ & $8,13 \pm 0,016$ & 0,62 \\
\hline & 250 & $1,52 \pm 0,002$ & $8,73 \pm 0,007$ & 0,69 \\
\hline & 500 & $3,28 \pm 0,015$ & $11,27 \pm 0$ & 1,16 \\
\hline \multirow[t]{3}{*}{ Ethyl acetate extract } & 5 & $0,83 \pm 0,001$ & $5,11 \pm 0,002$ & 0,73 \\
\hline & 15 & $0,80 \pm 0$ & $6,05 \pm 0,017$ & 0,60 \\
\hline & 30 & $1,37 \pm 0,002$ & $8,15 \pm 0,026$ & 0,76 \\
\hline \multirow[t]{3}{*}{ Methanol extract } & 50 & $0,71 \pm 0,041$ & $5,45 \pm 0,003$ & 0,59 \\
\hline & 100 & $0,88 \pm 0,004$ & $5,92 \pm 0,009$ & 0,68 \\
\hline & 200 & $1,31 \pm 0,003$ & $6,58 \pm 0,017$ & 0,90 \\
\hline \multirow[t]{3}{*}{ TOF extract } & 5 & $1,88 \pm 0$ & $5,89 \pm 0,003$ & 2 \\
\hline & 15 & $1,81 \pm 0,002$ & $7,98 \pm 0,024$ & 1,4 \\
\hline & 30 & $1,35 \pm 0,004$ & $6,58 \pm 0,024$ & 1,28 \\
\hline
\end{tabular}

$\beta$-gal: units of $\beta$-galactosidase; AP: units of phosphatase alkaline; IF: induction factor.

Positive control of genotoxicity (nitrofurantoin); NC: negative control (nontreated cells). extract), $71.18 \%$ (at a concentration of $200 \mu \mathrm{g} /$ assay of methanol extract) and $67.95 \%$ (at a concentration of $15 \mu \mathrm{g}$ /assay of ethyl acetate extract). Whereas, petroleum ether extract showed a relatively low efficiency in reducing nitrofuratoin induced genotoxicity, the IF decreased by about $30.5 \%$ at the concentration of $50 \mu \mathrm{g} /$ assay (Table 3).

\section{Evaluation of xanthine oxidase inhibition effect}

All the tested D. gnidium extracts, exhibited an inhibitory effect on xanthine oxidase activity in a concentration dependent manner. The weakest inhibitory effect was obtained in the presence of petroleum ether extract with a maximal inhibition percentage of $17.66 \%$ at $3 \mathrm{mg} /$ $\mathrm{ml}$. TOF and ethyl acetate extracts were the best inhibitors of xanthine oxidase activity with a maximal inhibition percentage of $100 \%$ at $1.5 \mathrm{mg} / \mathrm{ml}$ (Figure 1). The $\mathrm{IC}_{50}$ values of the tested extracts were $1.77,0.27,0.50$ and $0.28 \mathrm{mg} / \mathrm{ml}$ with chloroform, ethyl acetate, methanol and TOF extracts respectively (Table 4).

\section{Generation of superoxide anion detected by the non enzymatic NBT/Riboflavine system}

Methanol extract was the most potent superoxide scavenger in this assay. This extract induced a $57.4 \%$ (Figure 2) decrease of NBT photoreduction at a concentration of $0.5 \mathrm{mg} / \mathrm{ml}$ and an $\mathrm{IC}_{50}$ value of $0.35 \mathrm{mg} / \mathrm{ml}$. Whereas ethyl acetate and TOF extracts exhibited lower scavenging activity with an $\mathrm{IC}_{50}$ value of $2.19 \mathrm{mg} / \mathrm{ml}$ and $1.62 \mathrm{mg} / \mathrm{ml}$ respectively (Table 5). Chloroform, and petroleum ether extracts exhibited a pro-oxidant effect and increased the generation of $\mathrm{O}_{2}^{-}$in dose dependant manner. Chloroform extract seems to be the most important producer of superoxide radical as compared to petroleum ether extract (Figure 3).

\section{Discussion}

This study is designed to evaluate the antigenotoxic and antioxidant potential of $D$. gnidium extracts employing a variety of in vitro methods. The genotoxic and antigenotoxic activity were tested using the SOS chromotest which is a widely used assay for studying genotoxic and antigenotoxic activities of extracts/constituents from medicinal plants. This test employs the error-prone DNA repair pathway of E. coli PQ37, also known as the SOS response, a complex regulatory network that is induced by DNA-damaging substances $[26,35]$. The test involves incubation of the bacteria with the sample under investigation and subsequent determination of $\beta$ galactosidase $(\beta$-gal) activity. Alkaline phosphatase (AP) activity is also measured as a toxicity control. It was ascertained that different concentrations of D. gnidium extracts added to the indicator bacteria did not influence its viability and were non-genotoxic, except the TOF 
Table 3 Effect of D. gnidium extracts on the genotoxicity induced by nitrofurantoin (5 $\mu$ g/assay)

\begin{tabular}{|c|c|c|c|c|c|}
\hline Extracts & Doses ( $\mu \mathrm{g} /$ assay) & $\beta$-gal (UE) & PA (UE) & IF & Inhibition of genotoxicity (\%) \\
\hline Nitrofurantoin & 5 & $42,18 \pm 0,092$ & $11,19 \pm 0,0021$ & 23,56 & - \\
\hline NC & 0 & $3,07 \pm 0,024$ & $18,58 \pm 0,007$ & 1 & - \\
\hline \multirow[t]{3}{*}{ Petroleum ether extract } & 50 & $26,21 \pm 0,011$ & $9,82 \pm 0,019$ & 16,68 & $30,50^{*}$ \\
\hline & 250 & $26,65 \pm 0,041$ & $9,61 \pm 0,011$ & 17,31 & $27,70^{*}$ \\
\hline & 500 & $27,5 \pm 0,019$ & $9,87 \pm 0,007$ & 17,37 & $27,43^{*}$ \\
\hline \multirow[t]{3}{*}{ Chloroform extract } & 50 & $14,31 \pm 0$ & $7,05 \pm 0$ & 12,29 & $49,90^{* *}$ \\
\hline & 250 & $16,18 \pm 0,0169$ & $10,29 \pm 0$ & 9,53 & $62,19 * *$ \\
\hline & 500 & $4,66 \pm 0,047$ & $4,45 \pm 0$ & 6,35 & $76,28^{* *}$ \\
\hline \multirow[t]{3}{*}{ Ethyl acetate extract } & 5 & $8,19 \pm 0,019$ & $5,21 \pm 0$ & 9,53 & $62,18^{* *}$ \\
\hline & 15 & $7,18 \pm 0,0183$ & $5,29 \pm 0,0028$ & 8,23 & $67,95^{* *}$ \\
\hline & 30 & $7,93 \pm 0,0127$ & $5,68 \pm 0,007$ & 8,46 & $66,93 * *$ \\
\hline \multirow[t]{3}{*}{ Methanol extract } & 50 & $14,67 \pm 0,001$ & $9,48 \pm 0,08$ & 9,38 & $62,85^{* *}$ \\
\hline & 100 & $15,98 \pm 0,08$ & $10,55 \pm 0,04$ & 9,18 & $63,74^{* *}$ \\
\hline & 200 & $15,42 \pm 0,004$ & $12,464 \pm 0,042$ & 7,50 & $71,18^{* *}$ \\
\hline \multirow[t]{3}{*}{ TOF extract } & 5 & $19,73 \pm 0,014$ & $8,41 \pm 0,009$ & 14,66 & $39,45^{*}$ \\
\hline & 15 & $17,68 \pm 0,029$ & $7,04 \pm 0,007$ & 15,68 & $34,92^{*}$ \\
\hline & 30 & $14,76 \pm 0,009$ & $7,17 \pm 0,004$ & 12,87 & $47,38^{*}$ \\
\hline
\end{tabular}

$\beta$-gal: units of $\beta$-galactosidase; AP: units of phosphatase alkaline; IF: induction factor.

Positive control of genotoxicity (nitrofurantoin); NC: negative control (non-treated cells).

Results were expressed as percentage of inhibition of genotoxicity compared to the positif control (Nitrofurantoin). Values represent the mean \pm SD of three separate experiments. The statistical significance of results was evaluated by the Student's t-test. ${ }^{*} \mathrm{P}<0.05,{ }^{* *} \mathrm{P}<0.01$ means significant difference between positif control and treated sample.

extract which can be classified as marginally genotoxic with an IF value of 2 at the dose of $5 \mu \mathrm{g}$ /assay in the presence of $E$. coli $\mathrm{PQ} 37$. The results indicated that these extracts did not produce DNA lesions which block DNA synthesis, leading to the induction of SOS system. On

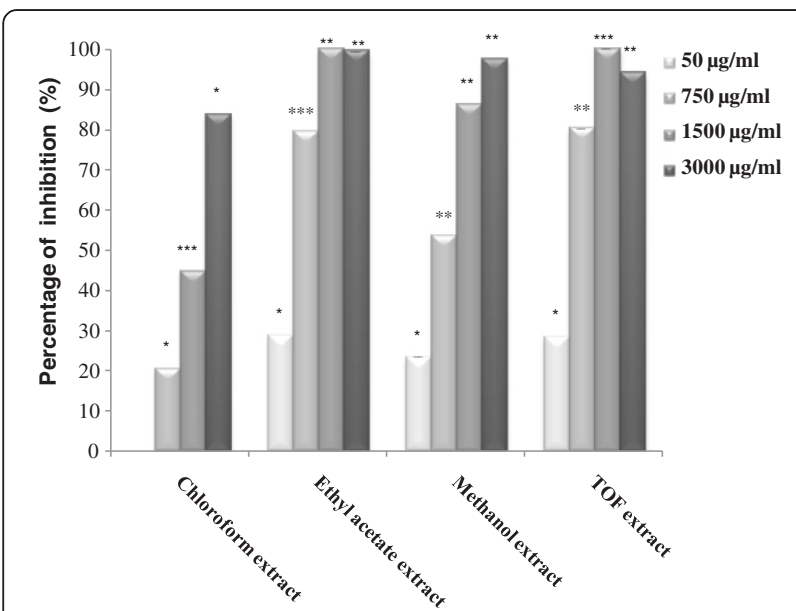

Figure 1 Inhibition of xanthine oxidase activity by $D$. gnidium leaf extracts. Results were expressed as percentage of inhibition of uric acid production compared to the control. Values represent the mean \pm SD of three separate experiments. The statistical significance of results was evaluated by the Student's t-test. ${ }^{*} P<0.05$, ${ }^{*} \mathrm{P}<0.01$, ${ }^{* * *} \mathrm{P}<0.001$ means significant difference between control and treated sample. the other hand, the tested extracts were effective in reducing the IF induced by the nitrofurantoin. In fact, our study showed that all tested extracts were able to reduce the level of DNA damage induced by the nitrofurantoin. These extracts may protect DNA strands from the electrophilic metabolites of the mutagen. Anti-genotoxic activity of the tested extracts may be ascribed to flavonoids [36] coumarins [37], and tannins [38,39] detected in TOF, methanol and ethyl acetate extracts. All these results confirmed our hypothesis that polyphenols contained in the tested extracts are responsible of their antigenotoxicity. In fact, our chemical study let to the identification of apigenin-7-glucoside from methanol and TOF extracts by HPLC analysis (data not shown). Zaabat et al. [40] showed, by SOS chromotest, that this compound prevent the genotoxicity produced by nitrofurantoin. The antigenotoxicity

Table 4 D. gnidium leaf extracts $I C_{50}$ for inhibition of xanthine oxidase activity

Extracts $\begin{gathered}\text { Inhibition of xanthine } \\ \text { oxidase activity } \mathrm{IC}_{50}(\mathrm{mg} / \mathrm{ml})\end{gathered}$

\section{Petroleum ether extract}

Chloroform extract

Ethyl acetate extract

Methanol extract 


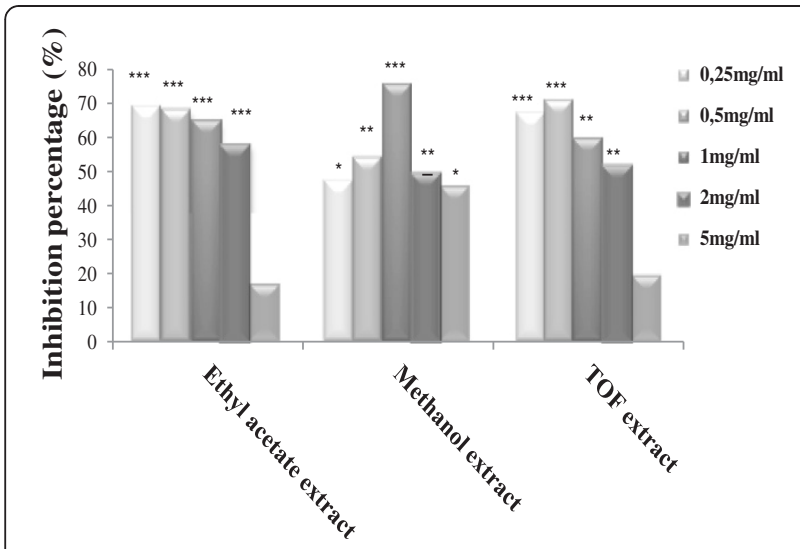

Figure 2 Antioxidant activity of ethyl acetate, methanol and TOF extracts towards superoxide anion generated by the non enzymatic system NBT/Riboflavine. Results were expressed as percentage of inhibition of superoxide anion generation compared to the control. Values represent the mean \pm SD of three separate experiments. The statistical significance of results was evaluated by the Student's t-test. ${ }^{*} \mathrm{P}<0.05,{ }^{* *} \mathrm{P}<0.01,{ }^{* * *} \mathrm{P}<0.001$ means significant difference between control and treated sample.

of ethyl acetate and chloroform extracts should be ascribed to the presence of terpenes (beta amyrin acetate) and lignans (dihydrosesamin) we detected in the two mentioned extracts. In fact, Nikolic et al. [41] reported that plant terpenes exhibited antigenotoxic activty. On the other hand Siddique et al. [42] demonstrated that a phenolic lignan (nordihydroguaiaretic acid), possesses an antigenotoxic potential against chlormadinone acetate induced genotoxic damage in mice bone-marrow cells.

We cannot however, exclude the possibility that other compounds with anti-genotoxic properties, participate in the anti-genotoxic effect of chloroform and petroleum ether extracts.

In order to investigate the mechanism by which the $D$. gnidium extracts exert their antigenotoxic effect, the antioxidant activity of the same extracts was evaluated. Use of at least two methods is recommended to assess and compare the antioxidant capacity of a given sample [43]. The present study presents different in vitro tests based either on the capacity to inhibit an enzymatic

Table 5 Superoxide free radicals scavenging effect of extracts from leaves of $D$. gnidium

\begin{tabular}{lc}
\hline Extracts & $\mathrm{IC}_{\mathbf{5 0}}(\mathrm{mg} / \mathrm{ml})$ \\
\hline Petroleum ether extract & - \\
\hline Chloroform extract & - \\
\hline Ethyl acetate extract & 2.19 \\
\hline Methanol extract & 0.35 \\
\hline TOF extract & 1.62 \\
\hline Quercitin & 0.6 \\
\hline - prooxidant effect. &
\end{tabular}

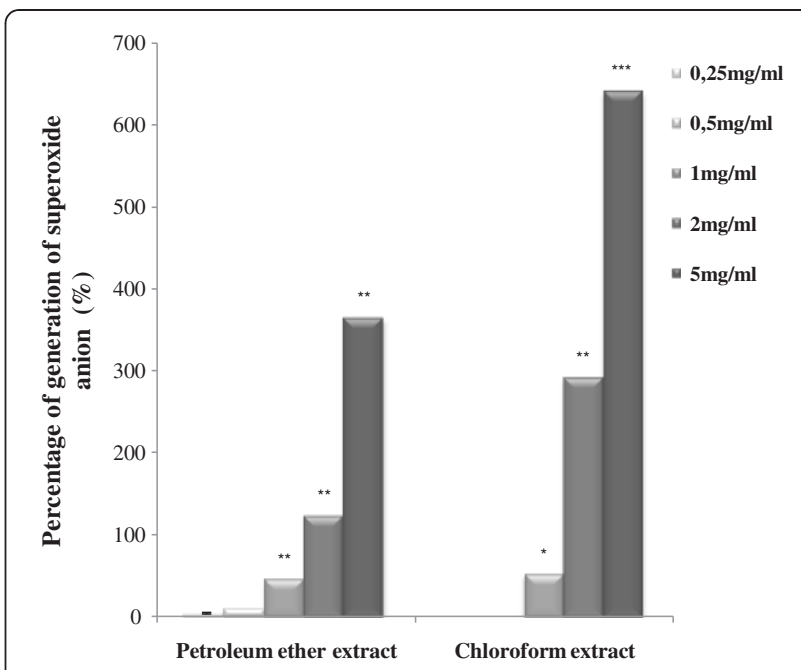

Figure 3 Pro-oxidant effect of petroleum ether and chloroform extracts towards superoxide anion generated by the non enzymatic system NBT/Riboflavine. Results were expressed as percentage of superoxide anion generation compared to the control. Values represent the mean \pm SD of three separate experiments. The statistical significance of results was evaluated by the Student's t-test. ${ }^{*} P<0.05,{ }^{*} P<0.01,{ }^{*}{ }^{*} P<0.001$ means significant difference between control and treated sample.

reaction involved in free radicals formation (xanthine oxydase assay) or to scavenge free radicals (superoxide anion). The xanthine oxydase is a flavoprotein which catalyses the oxidation of hypoxanthine to xanthine and generates superoxide anions and uric acid [44]. Consequently, xanthine oxidase is considered to be an important biological generator of superoxide radicals. These and other reactive oxygen species (ROS) contribute to the oxidative stress in the organism and are involved in many pathological processes such as inflammation, atherosclerosis, cancer, aging, etc. [45].

Likewise, a previous study on breast cancer cell line showed that extracts from $D$. gnidium roots have antiproliferative and apoptotic activity against MCF7 cells. Besides, the same study showed a pro-inflammatory effect of $D$. gnidium root extracts at high concentration via prostaglandins E2 (PGE2) and cyclooxygenases (Cox2) stimulation [46].

In addition our study on erythroleukemia cells showed that extracts from leaves of $D$. gnidium have antiproliferatif effect and induced a perturbation of K562 cell cycle. Chloroform extract inhibited human P-glycoproteinmediated daunorubicin efflux and enhanced intracellular accumulation of daunorubicin in K562/R7 leukemic cells in a dose dependant manner (data not shown). The inductive effect of $D$. gnidium extracts on the cytotoxicity of MCF7 and K562 cells may also probably be due to its antioxidant properties by perturbing the favorable redox condition and inducing cytotoxicity [47]. Under normal 
physiological conditions, the endogenous superoxide scavengers in the system protect tissues by neutralizing these radicals. This in vivo reaction is simulated in the in vitro model so as to use it as an analytical tool to evaluate the ROS scavenging abilities of natural products [48].

The xanthine/xanthine oxidase assay demonstrated that chloroform, methanol, ethyl acetate and TOF extracts were effective inhibitors of xanthine oxidase. In fact, the preliminary chemical study showed that ethyl acetate, methanol and TOF extracts are rich in flavonoids, a group of natural products exhibiting many biological and pharmacological activities. The inhibition of several enzymes by flavonoids has been demonstrated $[49,50]$. Also, it has been reported that flavonoids inhibit xanthine oxidase [51] and have superoxide scavenging activities. [52,53]. Therefore, it could be a promising remedy for human gout and ischemia by decreasing both uric acid and superoxide concentrations in human tissues [54].

The antioxidant activity of chloroform extract exerted by inhibiting xanthine oxidase activity can be attributed to beta amyrin acetate belonging to terpenes family. The apigenin-7-glucoside detected in both TOF and methanol extracts (data not shown) may participate to their antioxidant activity by inhibiting xanthine oxydase [30]. Luteolin-7-glucoside we identified in methanol extract (data not shown) should also be responsible at least in part,, of the antioxidant capacity this extract as described by Cimanga et al. [30].

Antioxidant capacity of D. gnidium extracts was also evaluated by their abilities to scavenge $\mathrm{O}_{2}^{-}$with the non enzymatic NBT/ Riboflavine system. Superoxide radical is known to be very harmful to cellular components as a precursor of more reactive oxygen species [55]. Photochemical reduction of flavins generates $\mathrm{O}_{2}^{-}$, which reduces NBT, resulting in the formation of blue formazan [30]. The results indicated that methanol extract was more effective in scavenging $\mathrm{O}_{2}{ }^{-}$than ethyl acetate and TOF extracts. This extract was also more active than the positive control, quercetin, in the assay. It seems that this activity is mostly related to the presence of phenolic compounds such as flavonoids in ethyl acetate, methanol and TOF extracts. The key role of phenolic compounds as scavengers of free radicals is emphasized in several reports [56]. In fact, we have identified, by HPLC, the presence of daphnetin in the methanol and TOF extracts (data not shown). It was reported that this coumarin have a radical scavenging and antilipid peroxidation effect [57]. As we have identified the presence of apigenin-7-glucoside in TOF extract and luteolin-7-glucoside in the methanol extract (data not shown), we believe that flavonoids are the most likely candidates among the compounds known to be present in TOF and methanol extracts, for preventing oxidative lesions and providing antigenotoxic effect [58,59].

Chloroform and petroleum ether extracts showed a pro-oxidant effect with the non enzymatic system NBT/ Riboflavin. In fact, several studies showing controversial results of exogenous antioxidants (including polyphenols) debating that the type, dosage and matrix of these antioxidants may be determining factors impacting the balance between beneficial and deleterious effects of these natural compounds [60]. There are also some proofs that they act as pro-oxidants, under certain conditions, such as high doses or the presence of metal ions [61-63]. The antioxidant or pro-oxidant activity intimately depends on their concentration [60]. Besiedes, some of the most abundant phenolic acids present in foods were reported to act as pro-oxidants: caffeic, chlorogenic, coumaric and ferulic acids [64-68].

\section{Conclusion}

The present study has demonstrated that some D. gnidium extracts possess potent antioxidant and antigenotoxic activities, which could be derived from compounds such as flavonoids and phenols. The antigenotoxic activity could be ascribed, at least in part, to their antioxidant properties but we cannot exclude other additionally mechanisms. However, further work is required to determine mechanisms involved in the antioxidant and antigenotoxic effects. In addition, in vivo evidence and identification of active phenolics involved is needed.

\section{Statistical analysis}

Data are expressed as the arithmetic means \pm SD of 3 separate experiments. The statistical significance of results was evaluated by the Student's t-test, with probability values of 0.05 being considered as significant.

\section{Competing interests}

The authors declare that they have no competing interests.

\section{Authors' contributions}

FC carried out SOS chromotest assay, NBT/riboflavin assay and Xanthine oxidase assay. JB carried out polyphenols, flavonoids and tannins quantification and contribute to the SOS Chromotest assay. AL carried out extract preparation. AN carried out photochemical analysis. SK prepared E.coli 37 and solutions which have been used for SOS chromotest, NBT/Riboflavine and xanthine oxidase assays. KG assisted with Daphne gnidium extraction and study design and interpretation. LCG helped conceive the study and helped in the preparation of the manuscript. All authors read and approved the final manuscript.

\section{Acknowledgments}

The authors are grateful to the Ministry of Higher Education and Scientific Research of Tunisia for the financial assistance of this study.

Received: 19 April 2012 Accepted: 8 September 2012

Published: 13 September 2012

\section{References}

1. Farnsworth NR, Akerele OO, Bingel AS, Soejarta DD, Eno Z: Medicinal plants in therapy. Bulletin World Health Organisation 1985, 63:965-981. 
2. Fasola TR, Egunyomi A: Nigerian usage of bark in phytomedicine. Journal of Plants People and Applied Research 2005, 3:73-77.

3. Chah KF, Eze CA, Emuelosi CE, Esimone CO: Antibacterial and wound ealing properties of mechanistic extracts of some Nigerian medicinal plants. J Ethnopharmacol 2006, 104:164-167

4. Rakuambo NC, Meyer JJM, Hussein A, Huyser C, Moilalose SP, Raidani TG: In vitro effort of medicinal plants used to treat erectile dysfunction on smooth muscle relation and human sperm. J Ethnopharmacol 2006, 105:84-88.

5. Obi RK, Iroagba II, Ojiako OA: Virucidal potential of some edible Nigerian vegetables. Afr J Biotechnol 2006, 5:1785-1788.

6. Jayaprakasha GK, Rao LJ: Phenolic constituents from lichen Parmotrema stuppeum (Nyl.) Hale and their antioxidant activity. Zeitschrift für Naturforschung 2000, 56:1018-1022.

7. Nogochi C, Nikki E: Phenolic antioxidants: A rationale for design and evaluation of novel antioxidant drugs for atherosclerosis. Free Radic Biol Med 2000, 28:1538-1546.

8. Kähkönen MP, Hopia Al, Vuorela HJ, Rauha JP, Pihlaja K, Kujala TS, Heinonen M: Antioxidant activity of plant extracts containing phenolic compounds. J Agric Food Chem 1999, 47:3954-3962.

9. Cardoso CRP, de Syllos Cólus IM, Bernardi CC, Sannomiya M, Vilegas W, Varanda EA: Mutagenic activity promoted by amentoflavone and methanolic extract of Byrsonima crassa Niedenzu. Toxicology 2006 225:55-63.

10. Déciga Campos M, Rivero Cruz I, Arriaga Alba M, Casta neda Corral G, Angeles López GE, Navarrete A, Mata R: Acute toxicity and mutagenic activity of Mexican plants used in traditional medicine. J Ethnopharmacol 2007, 110:334-342

11. Mohd Fuat AR, Kofi EA, Allan GG: Mutagenic and cytotoxic properties of three herbal plants from Southeast Asia. Trop Biomed 2007, 24:49-59.

12. Pottier-Alapetite G: Flore de la Tunisie: Angiospermes, Dicotylédones, Apetales, Dialypetales. Tunisia: Ministère de L'Enseignement Supérieur et de la Recherche Scientifique et Ministère de l'Agriculture; Tunis; 1979.

13. Vahl HH, Karbe L, Westendorf J: Mutagenicity testing of river sediments: comparison of Salmonella microsome test, arabinose resistence test, and umu test. Mutat Res 1997, 394:81-93.

14. Ziyyat A, Legssyer A, Mekhfi H, Dassouli A, Serhrouchni M, Benjelloun W: Phytotherapy of hypertension and diabetes in oriental Morocco. J Ethnopharmacol 1997, 58:45-54.

15. Bellakhdar J: La pharmacopée marocaine traditionnelle: Médecine arabe ancienne et savoirs populaires. France: Ibis Press; 1997.

16. Bruneton J: Eléments de Phytochimie et de Pharmacognosie. Paris: Techniques et Documentation-Lavoisier; 1987.

17. Cardon D: Le monde des teintures naturelles. Paris: Belin; 2003.

18. Charnot A: La toxicologie au Maroc. Rabat: Mémoire de la Soc. Sci. Nat. du Maroc; 1945. Edition Siège de I'I. S 717 pp.

19. Ghedira K, Chemli R, Richard B, Zeches M, Men-Olivier L: Contribution à l'étude de pharmacopée traditionnelle de Tunisie: Etude des parties aérienne d'Ajuga iva (L.) shreb. Plantes médicinales et phytothérapie 1991, 25:100-111.

20. Tona L, Kambu K, Ngimbi N, Cimanger K, Vlietnick AJ: Antiamoebic and phytochemical screening of some congolesse medical plants. J Ethnopharmacol 1998, 61:57-65.

21. Raman N: Phytochemical techniques. New Publishing Agency, New Delhi 2006, 19:32-40.

22. Yuan VY, Bone DE, Carrington F: Antioxidant activity of dulse (Palmaria palmata) extract evaluated in vitro. Food Chem 2005, 91:485-494.

23. Kumar A, Chattopadhyay S: DNA damage protecting activity and antioxidant potentiel of pudina extract. Food Chem 2006, 100:1377-1384.

24. Zhishen J, Mengcheng T, Jianming W: The determination of flavonoid contents in mulberry and their scavenging effects on superoxide radicals. Food Chem 1999, 64:555-559.

25. Nwabueze TU: Effect of process variables on trypsin inhibitor activity (TIA), phytic acid and tannin content of extruded African breadfruitcorn-soy mixtures: A response surface analysis. LWT- Food Sci Technol 2007, 40:21-29.

26. Quillardet $P Q$, Hofnung $M$ : The SOS chromotest, a colorimetric bacterial assay for genotoxins: procedures. Mutat Res 1985, 147:65-78.

27. Kevekordes S, Merch Sundermann V, Burghaus CHM, Spielberger J, Schmeiser HH, Arlt VM, Dunkelberg H: SOS induction of selected naturally occurring substances in Escherichia coli (SOS chromotest. Mutat Res 1998, 445:81-91.

28. Skandrani I, Limem I, Neffati A, Boubaker J, Ben Sghaier M, Bhouri W, Bouhlel I, Kilani S, Ghedira K, Chekir-Ghedira L: Assessment of phenolic content, free-radical-scavenging capacity genotoxic and anti-genotoxic effect of aqueous extract prepared from Moricandia arvensis leaves. Food Chem Toxicol 2009, 48:710-715.

29. Kong LD, Cai Y, Huang WW, Cheng CHK, Tan RX: Inhibition of xanthine oxidase by some Chinese medicinal plants used to treat gout. J Ethnopharmacol 2000, 73:199-207.

30. Cimanga K, De Bruyne T, Hu JP, Cos P, Apers S, Pieters L, Tona L, Kambu K, Vanden Berghe D, Vlietink AJ: Constituents from Morinda morindoides leaves as inhibitors of xanthine oxidase and scavengers of superoxide anions. Pharm Pharmacol Comm 1999, 5:419-424.

31. Oyangagui Y: Re-evaluation of assay methods and establishment of kit for superoxide dimutase activity. Anal Chem 1984, 142:290-296.

32. Liochev SI, Fridovich I: Superoxide from glucose oxidase or from nitroblue tetrazolium. Arch Biochem Biophys 1995, 318:408-410.

33. Beauchamp C, Fridovich I: Superoxide dismutase: improved assays and an assay applicable to acrylamide gels. Anal Biochem 1971, 44:276-287.

34. Banerjee A, Nabasree, De B: In vitro study of antioxidant activity of Syzygium cumini fruit. Food Chem 2005, 90:727-733.

35. Ames BN, Mc Cann J, Yamasaki E: Methods for detecting carcinogens and mutagens with Salmonella typhimurium/mammalian microsome mutagenicity test. Mutat Res 1975, 31:347-364.

36. Calomme M, Pieters L, Vlietink A, Berghe DV: Inhibition of bacterial mutagenesis flavonoids. Planta Med 1996, 92:222-226.

37. Choi JS, Park KY, Moon SH, Young HS: Antimutagenic effect of plant flavonoids in Salmonella assay system. Arch Pharm Res 1997, 17:71-75.

38. Lee KT, Sohn IC, Park HJ, Kim DW, Jung GO, Park KY: Essential moiety of antimutagenic and cytotoxic activity of hederagenin monodesmosides and bidesmosides isolated from the stem bark of Kalapanox pictus. Planta Med 2000, 66:329-332.

39. Baratto MC, Tattini M, Galardi C, Pinelli P, Romani A, Visioli F, Basosi R, Pongi $R$ : Antioxidant activity of galloyl quinic derivatives isolated from $P$. lentiscus leaves. Free Radic Res 2003, 37:405-412.

40. Zaabat N, Hay AE, Michalet S, Darbour N, Bayet C, Skandrani I, ChekirGhedira L, Akkal S, Dijoux-Franca MG: Antioxidant and antigenotoxic properties of compounds isolated from Marrubium deserti de Noé. Food Chem Toxicol 2011, 49:3328-3335.

41. Nikolic B, Mitic-Culafic D, Vukovic-Gacic B, Knezevic-Vukcevic J: Modulation of genotoxicity and DNA repair by plant monoterpenes camphor, eucalyptol and thujone in Escherichia coli and mammalian cells. Food Chem Toxicol 2011, 49:2035-2045.

42. Siddique $\mathrm{YH}$, Ara G, Beg T, Afzal M: Antigenotoxic effect of nordihydroguaiaretic acid against chlormadinone acetate-induced genotoxicity in mice bone-marrow cells. J Nat Med 2008, 62:52-56.

43. Sakanaka S, Ishihara Y: Comparison of antioxidant properties of persimmon vinegar and some other commercial vinegars in radicalscavenging assays and on lipid oxidation in tuna homogenates. Food Chem 2008, 107:739-744.

44. Cheng HY, Lin TC, Yu KH, Yang CM, Lin CC: Antioxidant and free radical scavenging activities of Terminalia chebula. Biol Pharmaceut Bull 2003, 26:1331-1335

45. Halliwell B, Gutteridge JM, Cross CE: Free radicals, antioxidants, and human disease: where are we now. J Lab Clin Med 1992, 119:598-620.

46. Chaouki W, Leger B, Liagre Y, Cherrah Y, Beneytout JL, Hmamouchi M: Roots of Daphne gnidium L. inhibit cell proliferation and induce apoptosis in the human breast cancer cell line MCF-7. Pharmazie 2009, 64:542-546.

47. Kilani-Jaziri S, Neffati A, Limem I, Boubaker J, Skandrani S, Ben Sghair M, Bouhlel I, Bhouri W, Mariotte AN, Ghedira K, Dijoux Franca MJ, ChekirGhedira L: Relationship correlation of antioxidant and antiproliferative capacity of Cyperus rotundus products towards K562 erythroleukemia cells. Chem Biol Interact 2009, 181:85-94.

48. Devi R, Arumughan C: Antiradical efficacy of phytochemical extracts from defatted rice bran. Food Chem Toxicol 2007, 45:2014-2021.

49. Vanden Berghe DAR, Haemers A, Vlietinck AJ: Antiviral agents from higher plants and an 375 example of structural-activity relationships of 3methoxyflavones. In Bioactive Natural Products: Detection, Isolation and 
Structural Determination. Edited by Colegate SM, Molyneux RJ. London: CRC Press; 1993.

50. Bors W, Heller W, Michel C, Saran M: Flavonoids as antioxidants: Determination of radical-scavenging efficiencies. Methods enzymol. 1990, 186:343-355.

51. Masayoshi I, Ayako M, Yoshiko M, Nahoko T, Michi F: Inhibition of xanthine oxidase by flavonoids. Agric Biol Chem 1985, 49:2173-2176.

52. Sichel G, Corsaro C, Scalia M, Di Bilio AJ, Bonomo RP: In vitro scavenger activity of some flavonoids and melanins against $\mathrm{O}_{2}$. Free Radical Bio Med 1991, 11:1-8.

53. Hu JP, Calomme M, Lasure A, De Bruyne T, Pieters L, Vlietinck A, Vanden Berghe DA: Structure activity relationship of flavonoids with superoxide scavenging activity. Biol Trace Elem Res 1995, 47:327-331.

54. Cotelle N, Bernier JL, Henichart JP, Catteau JP, Gaydou E, Wallet JC: Scavenger and antioxidant properties of ten synthetic flavones. Free Radical Bio Med 1992, 13:211-219.

55. Halliwell B, Gutteridge JM: The importance of free radicals and catalytic metal ions in human diseases. Mol Aspects Med 1985, 8:89-193.

56. Duenas $M$, Hernandez $T$, Estrella I: Assessment of in vitro antioxidant capacity of the seed coat and the cotyledon of legumes in relation to their phenolic contents. Food Chem 2006, 98:95-103.

57. Thuong PT, Manh HT, Minh NT, Ha DT, Sun MB, Jun KS, Tae SK, Choi JS, Bae $\mathrm{K}$ : Antioxidant activities of coumarins from Korean medicinal plants and their structure-activity relationships. Phytother Res 2010, 24:101-106.

58. Edenharder R, Grunhage D: Free radical scavenging abilities of flavonoids as mechanism of protection against mutagenicity induced by tertbutyl hydroperoxide or cumene hydroperoxide in Salmonella typhimurium TA102. Mutat Res 2003, 540:1-18.

59. Park KY, Jung GO, Lee KT, Choi J, Choi MY, Kim GT, Jung HJ, Park HJ: Antimutagenic activity of flavonoids from the heartwood of Rhus verniciflua. J Ethnopharmacol 2004, 90:73-79.

60. Bouaye J, Bohn T: Exogenous antioxidants-double-edged swords in cellular redox state. Health beneficial effects at physiologic doses versus deleterious effects at high doses. Oxid Med Cell Longev 2010, 3:228-237.

61. Decker E: Phenolics: prooxidants or antioxidants? Nutr Rev 1997, 55:396-398.

62. Raza H, John A: Green tea polyphenol epigallocatechin-3-gallate differentially modulates oxidative stress in $\mathrm{PC} 12$ cell compartments. Toxicol Appl Pharmacol 2005, 207:212-220.

63. Wätjen W, Michels G, Steffan B, Niering P, Chovolou Y, Kampkötter A, TranThi QH, Proksch P, Kahl R: Low concentrations of flavonoids are protective in rat H4IIE cells whereas high concentrations cause DNA damage and apoptosis. J Nutr 2005, 135:525-531.

64. Fukumoto L, Mazza G: Assessing Antioxidant and Prooxidant Activities of Phenolic Compounds J Agric Food Chem 2000, 48:8.

65. Maurya D, Devasagayam T: Antioxidant and prooxidant nature of hydroxycinnamic acid derivatives ferulic and caffeic acids. Food Chem Toxicol 2010, 48:3369-3373.

66. Vera Ḱ, Revilija M, Ivar S, Turid R: Antioxidant activity of phenolic acids in lipid oxidation catalyzed by different prooxidants. J Agric Food Chem 2009, 57:10377-10385.

67. Sakihama Y, Cohen MF, Grace SC, Yamasaki H: Plant phenolic antioxidant and prooxidant activities: phenolicsinduced oxidative damage mediated by metals in plants. Toxicology 2002, 177:67-80.

68. Simić A, Manojlović D, Šegan D, Todorović M: Electrochemical behavior and antioxidant and prooxidant activity of natural phenolics. Molecules 2007, 12:2327-2340

doi:10.1186/1472-6882-12-153

Cite this article as: Chaabane et al:: Antioxidant, genotoxic and antigenotoxic activities of daphne gnidium leaf extracts. BMC Complementary and Alternative Medicine 2012 12:153.

\section{Submit your next manuscript to BioMed Central and take full advantage of:}

- Convenient online submission

- Thorough peer review

- No space constraints or color figure charges

- Immediate publication on acceptance

- Inclusion in PubMed, CAS, Scopus and Google Scholar

- Research which is freely available for redistribution

Submit your manuscript at www.biomedcentral.com/submit
C Biomed Central 